винограда Донской ампелографической коллекции им. Я.И. Потапенко // Магарач. Виноградарство и виноделие. - 2018. - № 4. - С. 59-61.

8. Наумова Л.Г., Новикова Л.Ю. Использование метода последовательных разностей при создании агрометеорологических регрессионных моделей многолетних данных // Плодоводство и ягодоводство России. - 2018. - Т. 55. -С. 133 137. DOI 10.31676/2073-4948-2018-55-133-137.

9. Елисеева И.И., Курышева С.В., Костеева Т.В., Пантина И.В., Михайлов Б.А., Нерадовская Ю.В., Штрое Г.Г., Бартелс К., Рыбкина Л.Р. Эконометрика. М., 2007.

10. Novikova L.Yu., Naumova L.G. Structuring ampelographic collections by phenotypic characteristics and comparing the reaction of grape varieties to climate change // Vavilovskii Zhurnal Genetiki i Selektsii = Vavilov Journal of Genetics and Breeding. 2019. - 23(6). - C.772-779. - DOI 10.18699/VJ19.551.

11. Негруль А.М. Очерк семейства виноградных и его главных видов с их краткой хозяйственной характеристикой. Ампелография СССР. - Т.1. - М., 1946. C. 45-133.

DOI 10.18699/GPB2020-54

\title{
Продуктивность и качество зерна у раннеспелых сортов мягкой яровой пшеницы в Северном Зауралье
}

Новохатин В.В. *, к.с.-х.н., в.н.с.; Шеломенцева Т.В., н.с. НИИСХ Северного Зауралья - филиал ТюмНЦ СО РАН, г. Тюмень. *e-mail:vnovokhatin@bk.ru

Показаны сортовые различия по урожайности и основным технологическим показателям зерна. Выявлены сопряженные связи продуктивности с ее составляюшими, показателями качества зерна, поражаемостью патогенами и прорастанием зерна в колосе в предуборочный период. По урожайности и технологическим показателям зерна выделились сорта: Гренада, Тулунская 12, Тюменская 25, Ирень, Аделина, Новосибирская 31.

Ключевые слова: мягкая яровая пшеница, сорт, Урожайность, масса 1000 зерен, натура, протеин, клейковина.

\section{Productivity and quality of grain in early mature varieties of soft spring wheat in the northern Trans-Ural}

Novokhatin V.V., candidate of agricultural sciences, leading researcher, TV Shelomentseva, ns NIISH North-Urals - a branch of the Tyumen Scientific Center of the SB RAS, Tyumen, Russia.

*e-mail:vnovokhatin@bk.ru

Varietal differences in yield and main technological indicators of grain are 
shown. The interconnected relationships of productivity with its components, indicators of grain quality, pathogen susceptibility and sprouting of grain in the ear in the pre-harvest period were revealed. In terms of productivity and technological indicators of grain, the following varieties were distinguished: Grenada, Tulunskaya 12, Tyumen 25, Zlatozar and Adeline.

Key words: spring soft wheat, cultivar, yield, mass of 1000 grains, nature, protein, gluten.

Формирование урожая мягкой яровой пшеницы происходит под влиянием сильно варьирующих, в основном, не регулируемых факторов среды и сильно зависит от лим-факторов, проявление которых неравнозначно по годам [1]. Одним из основных является ограниченный период вегетации [2]. Установлено, что между урожайностью и длиной вегетационного периода корреляция высокая в засушливые годы, несколько ниже она в оптимальные по увлажнению годы и отсутствует в холодные годы [3]. Увеличение урожайности приводит к уменьшению содержания клейковины и белка, и увеличению массы 1000 зерен [4]. Крупность зерна является сортовым признаком [5-7] и одним из основных в формировании урожайности $[8,9]$. При этом селекция на крупнозерность более эффективна, чем на озерненность колоса [10]. Белковый комплекс зерно-клейковина - это косвенный показатель содержания белка. Эти признаки, а также показатель качества зерна, наряду с сортовыми особенностями [5] в сильной степени зависит от климатических условий [5] и в значительной степени - от технологии выращивания [6]. Прорастание зерна в колосе в предуборочный период, отрицательно влияет на продовольственные и семенные свойства зерна и семян [11]. Стекловидность зерна связана с его твердозерностью, содержанием белка и клейковины и является показателем мукомольных свойств зерна [5]. Поэтому увеличение урожайности и улучшение качества зерна, наряду с улучшением технологий возделывания, возможно только за счет новых, создаваемых сортов.

Исследования проводились в 2016-2019 гг. на опытном поле НИИСХ Северного Зауралья (г. Тюмень) в коллекционном питомнике «Музей», где из 60 распространенных (1929-2018 гг.) в регионе сортов - 19 раннеспелые.

Почва - темно-серая лесная, тяжелосуглинистая: $\mathrm{Ph}=6,0$; содержание гумуса - 3,5 \%; $\mathrm{NO}_{3}-4,2-5,2 ; \mathrm{P}_{2} \mathrm{O}_{5}-22,2-24,1 ; \mathrm{K}_{2} \mathrm{O}-18,7-22,0$ мг 100 г почвы. Предшественник - черный, удобренный $\mathrm{N}_{30} \mathrm{P}_{45} \mathrm{~K}_{30}$ кг д.в./га, пар. Посев сеялкой СКС-6-10, на делянках 5 м², повторность трехкратная, с нормой высева 650 всх.

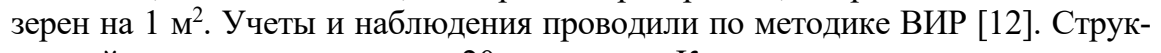
турный анализ проводился по 20 растениям. Качество зерна определялось по методическим указаниям оценки качества зерна [13] по следующим параметрам: масса 1000 зерен - ГОСТ 10842-76; стекловидность - ГОСТ-10987-76; натура (микронатура - ГОСТ-10840-64, микропурка $\left(10 \mathrm{~cm}^{3}\right)$ - конструкция 
СибНИИСхоза; содержание и качество клейковины - ГОСТ-13586.1-68. Математическую и статистическую обработку проводили по компьютерной программе О.Д. Сорокина [14].

Климатические условия были различными. Так, 2016 год был засушливым. При норме осадков за вегетацию 244 мм, их выпало 61 \%. Сумма температур $>10{ }^{\circ} \mathrm{C}$ составила $2163{ }^{\circ} \mathrm{C}$, при норме $1844{ }^{\circ} \mathrm{C}$. Прохладным и влажным характеризовался 2018 год, когда осадков за май-август выпало 307 мм, что на $26 \%$ выше нормы. Сумма активных температур - $1824{ }^{\circ} \mathrm{C}$, что ниже нормы. Увлажненным был 2019 год, с прохладной температурой в начале вегетации и в первой половине августа. По климатическим характеристикам, близким к среднемноголетним был 2019 год.

Результаты. В Северном Зауралье за период с 1929 по 2019 гг. получили распространение 60 сортов мягкой яровой пшеницы, из них раннеспелых - 19 (табл. 1). Среди последних - 10 сортов (со звездочками) зарегистрированы Госкомиссией. В большинстве своем они довольно хорошо адаптированы к местным агроклиматическим условиям. Однако возделывание культуры сильно зависит от проявления лим-факторов, одним из которых является ограниченный период вегетации. В условиях ограниченного периода вегетации Северного Зауралья у пшеницы отмечается направленно отрицательная, слабая сопряженность продуктивности с периодом «всходы-восковая» спелость (r=$0,211 \ldots-0,218)$ (табл. 2). Это является одним из объяснений отсутствия здесь в производстве позднеспелых сортов.

Высота растений - это важный хозяйственный показатель обуславливающий устойчивость к полеганию. Стебель является одним из основных признаков участвующих в фотосинтезе растений. Сопряженность продуктивности и высоты растений разнонаправленная. Она отрицательная в увлажненные годы $(\mathrm{r}=-0,418)$ и положительно выраженная $(\mathrm{r}=0,372)$ в засушливые годы. Оптимальная высота растений - 85-100 см. Устойчивость к полеганию во многом обусловлена диаметром второго нижнего междоузлия, которое положительно коррелирует с продуктивностью (r=0,471 ...0,501) (табл. 2). Отмечается положительная корреляция продуктивности $\mathrm{c}$ устойчивостью к полеганию $(\mathrm{r}=0,512 \ldots 0,548)$. Сопряженность урожайности с продуктивной кустистостью разнонаправленная $(\mathrm{r}=0,244 \ldots-0,408)$. В засушливых условиях она слабо положительная, а в различные по увлажненности годы - отрицательная. Поэтому урожай в регионе формируется за счет продуктивности главного колоса, на долю которого приходится до 70 \% урожайности. Следует отметить, что более урожайными являются сорта с выраженной плотностью колоса $(\mathrm{r}=0,368 . .0,826)$, у которых на 10 см стержня (расчетное) приходится 20-22 колоска. 


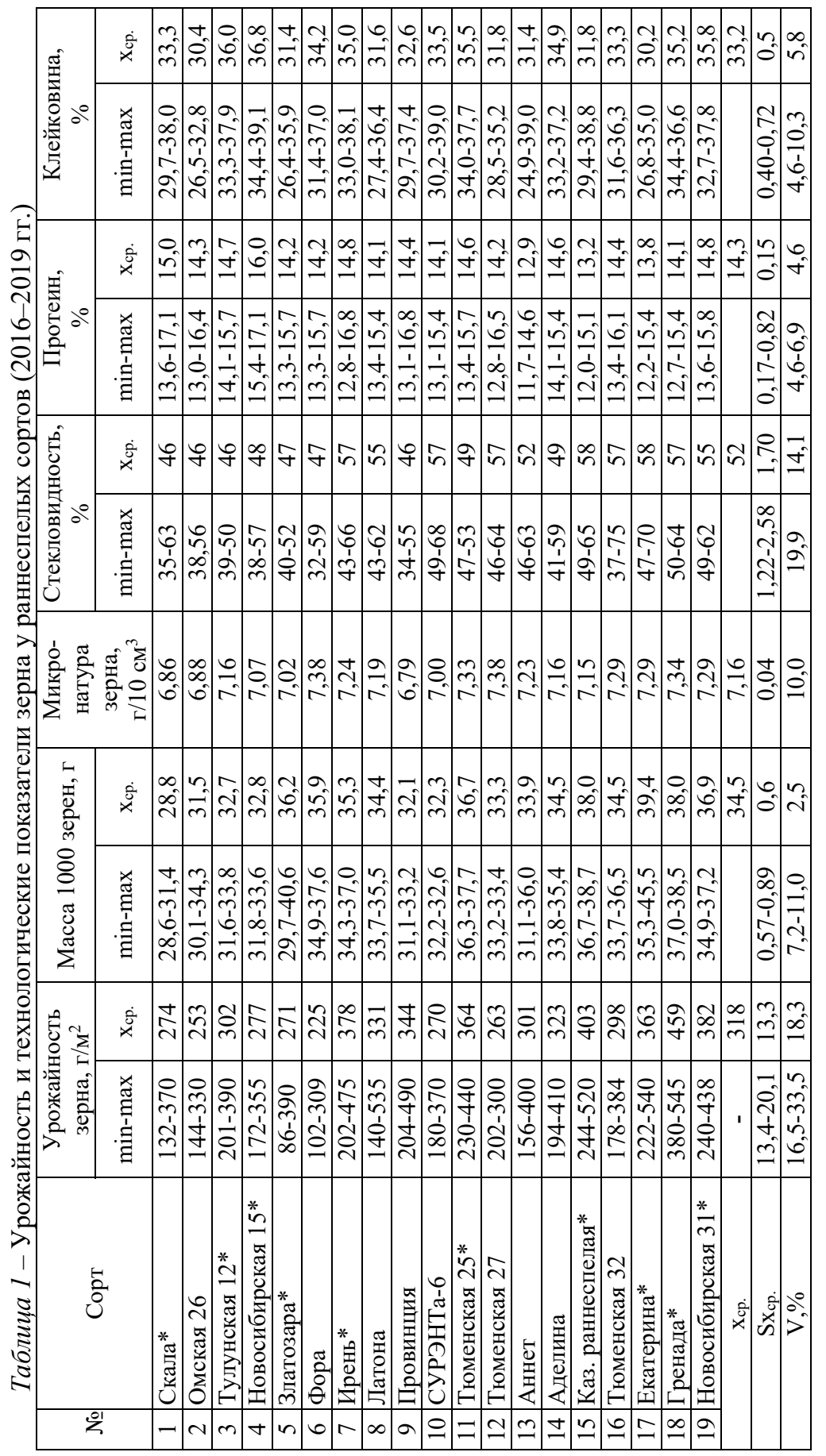


В контрастных условиях урожайность сортов, по годам, сильно варьирует $\left(16,5-33,5 \% ; x_{\mathrm{cp}}=18,3 \%\right)$ и колеблется от 86 до 545 г $/ \mathrm{M}^{2}$, при средней по опыту -318 г/м² и варьировании - 13,3 \% (табл. 1). Среди изученных сортов

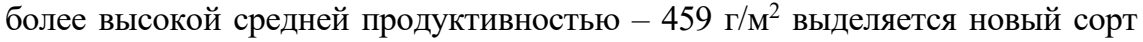
Гренада, у которого как минимальное $\left(380\right.$ г/ $\left.\mathrm{M}^{2}\right)$, так и максимальное $\left(545 \Gamma / \mathrm{M}^{2}\right)$ ее значения довольно высокие. При этом следует отметить, что в засушливом 2016 году, когда отмечена наименьшая урожайность, сорт по продуктивности значительно превысил все изучаемые генотипы. В провокационных условиях только Гренада обладает выносливостью к ржавчинным грибам и септориозу. Благодаря ускоренному прохождению формирования и налива зерна, сорта: Новосибирская 15, Провинция и Фора, имеют меньший тип поражения патогенами - 2 и процент поражения - 20-30 \%. Остальные сорта сильно поражаются названными грибами (3-4/60-80 \%). Корреляция между урожайностью и поражаемостью патогенами стабильно отрицательная $(\mathrm{r}=-0,304 \ldots-0,404)$ (табл. 2). В формировании урожайности масса 1000 зерен имеет большее значение $(\mathrm{r}=0,600 \ldots 0,701)$, чем озерненность колоса $(\mathrm{r}=0,342 \ldots 0,432)$. Между этими основными признаками продуктивности корреляция положительная $(\mathrm{r}=0,283 \ldots-0,413)$. Это позволяет, в разумных пределах, повышать их у вновь создаваемых сортов. При этом следует учитывать, что при меньшем варьировании абсолютной массы зерна $\left(7,2-11 \%\right.$; $\mathrm{x}_{\mathrm{cp}}=7,5 \%$ \% - выражающей ее консервативность, отбор в селекции на увеличение этого признака более эффективен, чем отбор на повышение озерненности колоса.

Таблица 2 - Корреляционные связи урожайности с признаками продуктивности, качества зерна и иммунитета

\begin{tabular}{|l|c|l|c|}
\hline \multicolumn{1}{|c|}{ Признак } & \multicolumn{1}{c|}{$\mathrm{r} \div \mathrm{r}$} & \multicolumn{1}{c|}{ Признак } & $\mathrm{r} \div \mathrm{r}$ \\
\hline всходы-восковая спелость & $-0,211 \div-0,218$ & масса зерна с колоса & $0,655 \div 0,750$ \\
\hline высота растений & $-0,418 \div 0,372$ & натура зерна & $0,464 \div 0,582$ \\
\hline диаметр II м.-узл. & $0,471 \div 0,501$ & протеин & $-0,359 \div-0,598$ \\
\hline полегание & $0,512 \div 0,548$ & клейковина & $-0,377 \div-0,539$ \\
\hline продукт кустистость & $0,244 \div-0,408$ & ИДК & $-0,328 \div-0,540$ \\
\hline плотность колоса & $0,368 \div 0,826$ & бурая ржавчина & $-0,377 \div-0,441$ \\
\hline масса 1000 зерен & $0,600 \div 0,701$ & септориоз & $-0,240 \div-0,251$ \\
\hline озерненность колоса & $0,342 \div 0,432$ & пыльная головня & $-0,304 \div-0,334$ \\
\hline прорастание зерна & $-0,312 \div-0,570$ & \\
\hline \multicolumn{4}{|c|}{$\mathrm{R} \geq 0,404$} \\
\hline
\end{tabular}

По массе 1000 зерен все изучаемые сорта крупнозерные. При этом несколько меньше абсолютная масса зерна у №№ 1-4, 9-10 ( $\mathrm{x}_{\mathrm{cp}}=30,2-32,8$ г) (табл. 1), более крупное оно у Гренады, Екатерины и Казахстанской раннеспелой $\left(\mathrm{x}_{\mathrm{cp}}=38,0-39,4\right.$ г). В благоприятных условиях крупным зерном выделяются Златозара $(40,6$ г) и Екатерина $(45,5$ г).

Натура зерна является одним из маркерных показателей его качества. 
Этот признак довольно стабильный ( $\mathrm{V}=2,5$ \%). Меньшей величиной микронатуры зерна характеризуются: Скала, Омская 26, Новосибирская 15, Златозара, Провинция, СУРЭНТа-6 (6,86-7,02 г/см³) (табл. 1), что следует учитывать при включении их в селекционные программы.

Стекловидность зерна, характеризующая его твердозерность и, в какой-то мере, белковость, проявилась в опыте в среднем на $52 \%$, несколько выше она (57-58 \%) у №№ 7, 10, 12, 15-18 (табл. 1). Следует отметить довольно выраженное варьирование признака - 10,0-19,9 \% ( $\mathrm{x}_{\mathrm{cp} .=14,1 \%) .}$ Наибольшая стекловидность отмечена в 2019 году у Екатерины и Тюменской $32(70-75 \%)$.

Среднее содержание протеина в зерне - 14,3 \%, с колебанием по сортам - 12,9-16,0 \%, большее у Новосибирской 15 и меньшее у Аннет. В благоприятных условиях максимальным проявлением признака выделяются: №№ $1,2,4,7,9,12$ (16,4-17,1 \%). Узким отношение между хорошим минимальным и максимальным проявлением протеина характеризуются: Тулунская $12(14,1-15,7 \%)$, Новосибирская $15(15,4-17,1)$ и Аделина $(14,1-15,4$ $\%)$, что повышает их селекционную значимость.

Клейковина - как белковый комплекс зерна является косвенным показателем протеина, что подтверждается стабильно высокой по годам положительной их сопряженностью $(\mathrm{r}=0,863 \ldots 0,878)$. Поэтому их проявление по годам имеет схожую изменчивость. Варьирование клейковины у сортов довольно значительное по годам - от 24,9 \% до 39,1 \% (табл. 1 ). При этом сильнее она проявилась в более благоприятных условиях 2019 года, а меньше в 2016 году. Большей средней величиной признака выделяются: Тулунская 12, Ирень, Тюменская 25, Аделина, Гренада и Новосибирская 31 (34,9-36,8 \%). У них же большая величина минимального проявления содержания клейковины - 33,0-34,4 \% и довольно высокое максимальное - 36,6-39,1 \%. Эту особенность, названных сортов, следует учитывать при включении их в селекционные программы, направленные на повышение качества зерна.

Показатель отношения содержания клейковины к протеину у сортов изменяется от 2,12 до 2,56. Более высокие значения показателя у №№ 3,6 , $11,15,18,19$ (2,41-2,50). При хорошем содержании протеина $(14,0-15,0 \%)$ и высоком - клейковины (35,0-36,8 \%) он косвенно оценивает хорошие хлебопекарные качества генотипов. Среди отмеченных сортов три - в списке сильных: Тулунская 12, Казахстанская раннеспелая, Новосибирская 31 и два в списке ценных - Тюменская 25, Гренада.

В данном наборе сортов только Новосибирская 15 и Златозара показали первую группу качества клейковины (73 ед. ИДК). В пределах 78-80 ед. ИДК у Екатерины, Казахстанской раннеспелой, Тюменской 32, Гренады. Все остальные сорта однозначно формируют вторую крепкую клейковину.

Заключение. Высота растений отрицательно коррелирует с продуктивностью во влажные годы и положительно - в засушливые, что характерно и 
для продуктивной кустистости. Высокой средней урожайностью выделяется Гренада. Крупнозерность характерна для Златозары и Екатерины. Повышенным содержанием протеина выделяются: Тулунская 12, Новосибирская 15, Аделина и клейковины - они же, а также - Ирень, Тюменская 25 и Новосибирская 31. Выделенные сорта представляют производственную ценностью и рекомендуются для использования, в качестве исходного материала, в селекции на повышение продуктивности и качества зерна.

\section{Список литературы}

1. Драгавцев В.А., Генетика признаков продуктивности яровых пшениц в Западной Сибири / В.А. Драгавцев, Р.А. Цильке, Б.Г. Рейтер, Б.А. Воробьев, А.Г. Дубровская, Н.И. Коробейноков, В.В. Новохатин, В.П. Максименко, А.Г. Бабакишиев, В.Г. Илющенко, Н.А. Калашник, Ю.П. Зуйков, А.М. Федотов - Новосибирск: Наука, 1982. $-230 \mathrm{c}$.

2. Новохатин В.В. Селекция яровой мягкой пшеницы в Северном Зауралье / В.В. Новохатин // Научные результаты агропромышленному производству. Сб. науч. тр. - Курган: Зауралье, 2004. - С. 214-218.

3. Мовчан В.К. Морфологические особенности и продуктивность яровой пшеницы в зоне Северного Казахстана / В.К. Мовчан // Селекция и семеноводство полевых культур. - М.: Колос, 1974. - С. 121-184.

4. Ведров Н.Г. Яровая пщеница в Восточной Сибири / Н.Г. Ведров - Красноярск: КрасГАУ, 1998. - 312 с.

5. Козьмина Н.П. Зерно / Н.П. Козьмина - М.: Колос, 1969. - 368 с.

6. Коданев И.М. Повышение качества зерна / Коданев И.М. - М.: «Колос», 1976. - C. $225-236$.

7. Шеломенцева Т.В. Изучение исходного материала мягкой яровой пшеницы для селекции на продуктивность / Т.В. Шеломенцева // Генофонд и селекция растений. Материалы IV Международной научно-практической конференции 04-06.04.2018 г. - Новосибирск, 2018. - С. 454-459.

8. Кузьмин В.П. Селекция и семеноводство зерновых культур в Целинном крае Казахстана / Кузьмин В.П. - М. - Целиноград: Колос, 1965. - 199 с.

9. Кумаков В.А. Физиология яровой пшеницы / В.А. Кумаков - М.: Колос, 1980. $-207 \mathrm{c}$.

10. Воробьев В.Ф. О связи урожайности с элементами структуры урожая / В.Ф. Воробьев // Селекция и семеноводство, 1972. № 5. - С. 25-27.

11. Новохатин В.В. Устойчивость яровой мягкой пшеницы к предуборочному прорастанию зерна / Новохатин В.В. // Тюменское обеспечение агропромышленного комплекса «Тюменской области». - Новосибирск, 2003. - С. 152-172.

12. Методические указания по изучению мировой коллекции пшеницы. Под. Ред. В.Ф. Дорофеева. Л.: ВАСХНИЛ, 1977. 177 с.

13. Методические указания по оценке качества зерна. М.: ВАСХНИЛ,1977. 177 с.

14. Сорокин О.Д. Прикладная статистика на компьютере. - Краснообск: ГУП РПО СО РАСХН. 2004. -162 c. 